\title{
Markaların Sosyal Aracılı Krizlerle Mücadelesinde Yeni Yaklaşımlar: Fairy Krizi Örneği
}

BaşvuruTarihi: 20.02 .2021 Yayın Kabul Tarihi: 14.04 .2021 Yayınlanma Tarihi: 30.04 .2021

\author{
Zeynep Genel $^{1}$ \\ Okan Üniversitesi, Uygulamalı Bilimler Fakültesi, \\ Halkla ilişskiler ve Reklamcılık Bölümü, İstanbul \\ zeynep.genel@okan.edu.tr \\ ORCID: 0000-0002-3140-0053 \\ Eren Erdem ${ }^{2}$ \\ Okan Üniversitesi, Uygulamalı Bilimler Fakültesi, \\ Halkla ilişkiler ve Reklamcılık Bölümü, İstanbul \\ ereerdem@stu.okan.edu.tr
}

(iD) ORCID: 0000-0001-5192-4762

\section{ÖZ}

Sosyal medyanın değişen dinamikleri, kullanıcıların bilgi edinme ve kanaat edinme alışkanlıklarını değiştirmiş bu durum markaları da yeni nesil krizlerle daha sık karşı karşıya getirmeye başlamıştır. Sosyal medya boykotları üzerinden markaların yaşadığı krizler itibarlarına ciddi hasar verebilmekte, çevirim içi iletişimlerinde uzun süre olumsuz etki yaratabilmektedir. Bu alana yönelen araştırmalar ise gün geçtikçe artmakta ve markalara yön veren bulgular sunmaktadır. Bu çalışma bu kapsamda 24 Ocak 2020 tarihinde yaşanan Elazığ Depremi sonrasında reklam yüzü Berna Laçin'in deprem vergilerine yönelik Twitter paylaşımı ve bu paylaşımın etkisiyle kullanıcıların negatif tepkisi ile karşı karşıya kalan Fairy markasının sosyal medyada yaşadığı krizi örnek vaka olarak ele almaktadır. Çalışma, örnek krizi Durumsal Kriz iletişimi Teorisi çerçevesinde ele almaktadır. Bu doğrultuda sosyal izleme yöntemi ile krizin evrelerini, süreçlerde iletişimsel etki ve tepki silsilesini analiz etmektedir. Çalışmadan elde edilen en önemli iç görü sessizlik taktiği ile yaşanılan krize dahil olmayan markanın bu krizden markanın online imajı açısından olumsuz etkilendiğidir. Çalışmanın amacı sosyal medyada markaların karşılaştıkları krizlerin süreçsel analizini bir örnek vaka ile ele alarak bu alandaki çalışmalara katkı sağlamaktır.

Anahtar Kelimeler: Sosyal medya kaynaklı krizler, sosyal aracılı krizler, çevirim içi kriz iletişimi, durumsal kriz iletişim teorisi, sosyal izleme.

\footnotetext{
1 Doktor Öğretim Üyesi

${ }^{2}$ Uzman
} 


\title{
New Approaches to the Clash of Brands with Social Mediated Crisis: The Case of Fairy Crisis
}

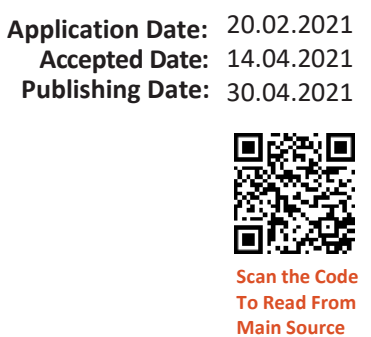

Application Date: 20.02 .2021 Accepted Date: 14.04.2021 口落回 Main Source

\author{
Zeynep Genel ${ }^{3}$ \\ Okan University, Faculty of Applied Sciences, \\ Department of Public Relations and Advertising, istanbul \\ zeynep.genel@okan.edu.tr \\ (D) ORCID: 0000-0002-3140-0053 \\ Eren Erdem ${ }^{4}$ \\ Okan University, Faculty of Applied Sciences, \\ Department of Public Relations and Advertising, istanbul \\ ereerdem@stu.okan.edu.tr \\ ORCID: 0000-0001-5192-4762
}

\begin{abstract}
Changing dynamics of social media have shaped the consumers' habits of obtaining information and perception, therefore brands face new generation crisis more often than before. Crises experienced by brands through social media boycotts can seriously damage their reputation and have a long-term negative impact on their online communications. Crisis research in this field is increasing day by day and offers findings that direct brands. In this context, this study handles the crisis of the Fairy brand as an exemplary case which face a Twitter crisis due to the brand's voice Berna Laçin's Twitter post after Elazığ Earthquake at 24 January 2020. The study handles the sample crisis case in scope of Situational Crisis Communications Theory. In this respect, social monitoring method applied due to analyse the phases of crisis, the impact of interaction and the response of audiences to the brand. The main insight of findings is the brand image affected negatively due to the brand crisis response strategy. The study aims to contribute to the field by taking advantage of the rising trend of case studies and social listening in crisis research.
\end{abstract}

Keywords: Social mediated crisis, social media crisis, online crisis communications, situational crisis communication theory, social monitoring.

\footnotetext{
${ }^{3}$ Assistant Professor

${ }^{4}$ Specialist
} 


\section{GiRiş}

Illetişimin dijitalleşmesi ve kullanıc etkileşiminin iletişim sürecine eş zamanlı dahil olmasıyla birlikte markalar yeni zorluklar ve sorunlarla karşı karşıya kalmaktadır. Bu sorunların en sık rastlananlarından biri sosyal medya kaynaklı iletişimsel krizlerdir. Sosyal aracılı krizler olarak kavramaştırılan bu krizler, markadan kaynaklı veya farklı bir durumdan kaynaklı olabilmektedir. Krizlerde markanın iletişim davranışını veya krize karşı vereceği yanıtın ne olacağııın belirleyicisi dijital iletişim öncesinde çoğunlukla markadan kaynaklı olmasına veya olmamasına bağlı olurken, günümüzde bu sorumluluk sosyal medyada oluşan algıya göre değişebilmektedir. Markalar veya kurumlar olası krizlere yönelik önceden proaktif eylem planları geliştirebildiği gibi, krizin yarattığı duruma ve etkiye bağıı olarak kriz anında da planlanmamış, eylemsel reaktif stratejiler uygulayabilmektedirler. Krize verilecek yanıt belirlendikten sonra hangi iletişim stratejisi ile tepki verileceği de krizin yönetimi ve itibara etkisi konusunda belirleyici unsurlardan biridir. Bu süreçte oluşan iletişimsel ve sosyo-psikolojik durum, kurum veya markaların nasıl aksiyon alacağı veya nasıl reaksiyon göstereceğini etkiler niteliktedir. Sosyal medyanın sosyal hayata yoğun şekilde entegre olması, geçmişte dolaylı olarak markanın dahil olduğu kriz tipleri günümüz krizlerinde markanın sorumlu görüldüğü krizlere dönüştürebilmektedir. Bu durum ön görülemez bazı kriz tiplerini markanın ön görebilmesi gerekliliğini de beraberinde getirmektedir.

Markanın kriz durumunu ön görebilmesi, krize vereceği yanıtı verilerle dayanaklandırması ve krizin algısal etkilerini ölçümleyerek olası krizlere veri sağlamayabilmesinde kriz dönemi araştırmaları önemli katkı sağlayabilmektedir. İletişim çalışmalarında planlama sürecinin belirleyicisi olan araştırmalar, ön görülemeyen durumlara karşı reaksiyon geliştirebilmek açısından da önemlidir.

Bu doğrultuda bu çalışma sosyal medya kaynaklı krizlere bir vaka analizi üzerinden kalitatif araştırma yöntemlerinden yararlanarak süreç ve etkileşim boyutunda katkı sağlamayı amaçlamaktadır. Çalışmanın ilk kısmında kriz iletişimi, sosyal medyada krizler Coombs ve Holladay'in yaklaşımları çerçevesinde kavramsal olarak incelenmekte, ikinci bölümde ise örnek vakadan elde edilen veriler yargısal analiz yöntemi ile aktarılmaktadır. Ocak 2020 tarihinde gerçekleşen bu sosyal medya odaklı tepkinin Twitter üzerinden analizi ve markanın verdiği ilk tepkilerin etkisi Durumsal Kriz İletişimi yaklaşımı çerçevesinde süreç-şiddet açısından analiz edilerek alana katkı sağlamak amaçlanmaktadır.

\section{Sosyal Medya ve Sosyal Aracılı Krizler}

Sosyal medya, kişinin zaman ve ortam kısıtlaması olmadan dilediği anda düşüncelerini beyan ettiği, ürettiği veya var olan içeriği paylaştığı, başkalarının fikirlerine ulaştığı, diğer kullanıcılar tarafından üretilen içerikleri tükettiği, insanlar ve kurumlarla etkileşim kurup vakit geçirebildiği bir çevrimiçi haberleşme alanıdır. Dijk (2012), sosyal medyayı "hem bireysel hem sosyal 


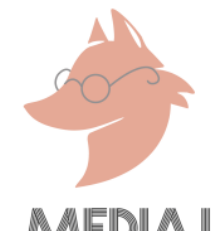

dünyaları bağlayan bir uzam" olarak tarif eder (s.251). 2,449 milyar Facebook, bir milyar Instagram, 339,6 milyon Twitter ile dünya nüfusunun 3,8 milyarı aktif olarak sosyal medya kullanırken (We are Social,2020), Türkiye ise 62 milyon kullanıcı ile Avrupa'nın sosyal medyada en çok vakit geçiren ülkesidir. Türkiye'de kullanıcılar her gün yaklaşık iki saat 51 dakikasını eğlenmek ve sosyalleşmek için sosyal medya uygulamalarında geçirmektedir (We are Social,2020). Sosyal medyanın gündelik hayatta gittikçe daha fazla yer edinmesi, bilgi ve iletişim ağının da çevresel olarak sosyal medyada artmasına yol açmakta, bu artış beraberinde avantajlar kadar dezavantajları da getirmektedir. Kotler'e (2010) göre bu değişim markalara, kar odaklı yaklaşımlarını indirgeyerek, sosyal ve kapsayıcı yaklaşımlar geliştirmek zorunluluğunu getirmiştir. Bunun temel nedeni, sosyal medya kullanımı yaygınlaştıkça, kitlelerin etkileşim nedeniyle daha duyarlı ve daha kolektif hareket etmeye eğilim göstermeleridir. Edelman'ın 2018 Güven Barometresi'nin verileri, markaların paylaştıkları içeriklerin kullanıcıların \%65'inin olumlu veya olumsuz görüş ve yorum yapmalarında etkili olduğunu göstermektedir. Olumlu görüş ve yorumlar markaların online imajlarına katkı sağlarken, olumsuz görüş ve paylaşımlar ise markaların imajını olumsuz yönde etkileyebilmektedir. Brandscore 2018 araştırması, sosyal medya kullanıcılarının \%21 kadarının sosyal medyada markalar için olumsuz yorumlarda bulunduğunu ortaya koymaktadır. Edelman Güven Barometresi 2018 yılı verilerine göre," kullanıcıların \%45'i sosyal medyada bir marka ile ilgili nefret içeren veya olumsuz içeriklerin yine markadan kaynaklı olduğunu düşünmektedirler" (s. 16). Kullanıcılar tarafından paylaşılan olumsuz sosyal medya içerikleri, markanın karşı karşıya kaldığı bir kriz durumunda kullanıcıların tekrar karşısına çıkabilmekte ve markanın bu süreci yönetmesini zorlaştıran bir etken olabilmektedir.

Sosyal medyanın yaygınlaşması ve bireyin gündelik pratiğinde baskınlaşması, sosyal aracılı (social-mediated) krizlerin önemini artırmaktadır. Sosyal aracılı krizler, dijital platformlarda doğan ve sosyal medya aracılığıyla etkileşimin yarattığı gürültüde baskın olan söylemin bir boykot veya linçe evirilmesiyle krize dönüştüğü durumlardır.

Günümüzde sosyal aracılı krizlerde, hedef kitlenin tepkisine yönelik markanın iletişim davranışı markalar açısından önemlidir. Bu iletişim davranışının krizin şiddetini yönetmekte ne denli etkili olabildiğinin kanıtı geçtiğimiz yıllarda yaşanan Nike krizi örneğinde görülmektedir. Dünyanın en büyük spor giyim markalarından olan Nike düzenlediği Just Do It (Sadece Yap) kampanyasında ünlü NFL sporcusu Colin Kaepernick'i reklam yüzü olarak kullanmıştır. Kaepernick maç öncesi birtakım siyasi nedenlerden dolayı protesto gerçekleştirmiştir. Büyük tepki çeken bu protestoya karşı insanlar Twitter'da \#JustBurnlt (Sadece Yak) etiketi ile markaya tepki göstermiş ve Nike ürünlerini yaktıkları fotoğrafları bu etiket ile paylaşmışlardır (HaberTürk, 5 Eylül 2018). Marka bu boykot esnasında geri çekilmeyerek yanıt vermeyi tercih etmiş ve yüzde üç değer kaybına uğramasına rağmen uzun vadede sosyal dinlemeyi etkin kullanması sayesinde krizden başarıyla çıkan markalar arasında yer almayı başarmıştır (Kim, Overton, Bhalla ve Li, 2019). Hedef kitlenin tepkisi karşısında doğru iletişim taktiklerini tercih eden markaların daha kolay bu süreçleri yönetebildikleri gözlemlenmektedir. 


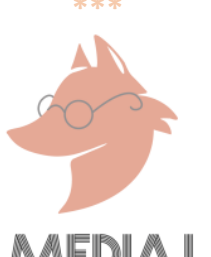

Avrupa Gıda Güvenliği Otoritesi'nin palm yağının kanserojen madde içerdiğini açıklaması üzerine Nutella markası, sosyal medya aracılı bir saldırı ile hedef gösterilerek, sosyal medyada bir boykot ile karşı karşıya kalmıştır (Cova ve D’antone, 2016). Bunun üzerine marka, sessiz kalmayarak, paydaşlarının farkındalığını arttıracak bir bilgilendirme stratejisi tercih etmiştir. Bu doğrultuda palm yağının 200 derecenin üzerinde sıcaklığa maruz kalırsa tehlikeli hale gelebildiğini ve kendi ürünlerinde en fazla 80 derece kullandıklarını anlatan bir reklam kampanyası başlatmıştır (Ntv,18 Ocak, 2017). Markanın oluşturduğu sadakat ve sosyal dinlemedeki başarısı, yaşadığı bu kriz sürecini en iyi şekilde atlatabilmesi için çok önemli bir destek olmuştur. 2016 yılında yapılan bir araştırmaya göre, marka ile iyi geçmişi olan toplulukların Nutella'nın yaşadığı bu krizi yönetmede olumlu etkisi olduğu görülmektedir (Cova ve D’antone, 2016). Wilder'a (2015) göre “Marka savunuculuğu, tüketicilerin bir marka hakkında çok tutkulu hisleri olduğunda, diğerlerine karşı markayı desteklediklerinde ve muhaliflere karşı savunduklarında oluşmaktadır" (aktaran Öksüz ve Kölgelier, 2019, s. 1316). Markanın yaşadığı bu süreçte sosyal medyada incelenen yorumlardan 488'i markayı suçlayıcı ve satın almamaya yönelik paylaşım, 116 tanesi konu ile ilgili bilgi edinme amaçlı paylaşımdır. Buna karşın 488 adet markanın tüketicileri aleyhine bir şey yapmayacağına dair güven belirten ve markaya destek içeren yorumlardan oluşmaktadır (Öksüz ve Kölgelier, 2019). Bu boykot sürecinin marka ve tüketici açısından sonuçlarını gösteren Zenna araştırma raporuna göre, tüketicilere marka satın alma değişiklikleri sorulduğunda \%37'sinin satın almayı bıraktığını, \%21'inin boykot sürecinde bıraktığını fakat daha sonra satın almaya devam ettiğini, \%14'ünün yaşanılan bu sürecin kendisini etkilemediğini ve satın almaya devam ettiğini ve \%28'inin zaten kullanmadığı tespit edilmiştir (Öksüz ve Kölgelier, 2019). Bir kriz alanı olarak sosyal medya, olumsuz yorumların sonsuza kadar kalıcı olduğu uzamdır. Bu nedenle sosyal medyada yaşanan iletişimsel krizlerin ilk döneminde markanın sadık tüketici grubunun olumlu yorumları negatif algıyı nötralize etmek açısından önemlidir. Markanın sosyal medya odaklı krizleri yönetmesinde önemli olan bir diğer nokta ise iyi sosyal dinleme yapabilmesi ve iki tarafın beklentilerini orta noktada buluşturabilecek bir geri bildirimde bulunabilmesidir. Doğru iletişimsel kararlar, markanın yalnız nihai tüketicileri açısından değil, itibarının finansal değeri olan yatırımcıları ve destekçileri açısından da hayati önem taşımaktadır. Zira birçok kriz markaların hisse değerlerini de geriletebilmektedir. Bu açıdan Türkiye'de sosyal medyada gerçekleştirilen ve kurumun finansal kaybına örnek teşkil edebilecek bir kriz örneği Turkcell markasının karşı karşıya kaldığı krizdir. Ensar Vakfı'nın 2016 senesinde karıştığı bir krizden sonra Turkcell vakfa sponsorluğunu sürdürmesiyle, sosyal medya kullanıcıları tarafından Turkcell karşıtı paylaşımlarla ve ağırlıklı olarak Twitter platformu üzerinde bir kampanya başlatılmıştır (Sputnik, 12 Aralık 2017). Bunun üzerine Turkcell, yıllardır olduğu gibi eğitime desteklerini sürdüreceklerini ve vakfa desteğe devam edeceklerini kamuoyuna duyurmuştur. Sosyal medyadaki bir grup hedef kitle tarafından Turkcell'den bir özür ve sponsorluk geri çekme hamlesi beklenirken, marka tam tersine vakıf ile ilgili herhangi bir anlaşma iptali yapmamıştır. Marka, kendisi hakkında sosyal medya üzerinden boykot mesajı paylaşan ve markayı eleştiren sosyal medya kullanıcılarına da davalar açmışır (Kaya, 2019). Bunun sonucunda Kalaycı'nın çalışmasında belirttiği gibi "Turkcell'in kriz sonrasında 3. çeyrek net karı 2015 yılına göre yüzde 71,2 düşerek, 631,3 milyon TL'den 181,7 


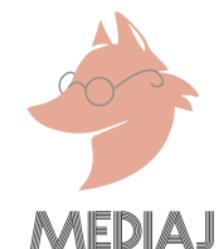

milyon TL'ye gerilemiştir. 673 bin abonesi hattını bir başka operatöre taşımıştır" (2017, s. 337). $\mathrm{Bu}$ örnekte de görüldüğü üzere markalar kriz nedeniyle ciddi ekonomik kayıplar yaşayabilmektedir.

Türkiye'de sosyal medya kaynaklı yaşanan krizlere bir diğer örnek ise Borusan'ın yaşamış olduğu kriz sürecidir. Sosyal medyada Borusan'ın eski yarış pilotu Burcu Çetinkaya ile olan sponsorluk anlaşmasını başörtüsü yüzünden iptal ettiği iddia edilmiştir (Gökmen, t.y). Zira Burcu Çetinkaya ve Merve Sena Kılıç televizyon programını başörtülü olarak sunmaya başlamıştır. Yenişafak Gazetesi, Marka Müdürü Hakan Bayülgen'in Çetinkaya ile görüşerek bu durumda sponsorluğa devam etmek istemediklerini, başörtüsünün marka açısından uygun olmadığını iddialarını Bayülgen'e ulaşarak ve doğrulayarak haberleştirmiştir (Yenişafak Gazetesi, 28 Aralık 2011). Bunun üzerine birçok yayın kuruluşu ve sosyal medya kullanıcısı markaya karşı sert tepki göstermiştir. Markanın, iptalin nedeninin başörtüsü değil mali sebepler olduğunu duyurması, kamuoyu tarafından inandırıcı bulunmamıştır. Bunun ardından marka gazetelere verdiği tam sayfa ilan ile yaşanan olaylardan dolayı üzgün olduğunu bildirmiştir. Borusan'ın bu şekilde gazetelere tam sayfa üzgünüz ilanı vermesi, markanın kriz iletişimi yönetimini süreç açısından hatalı yürüttüŭğ, bu ilanlar ile olaydan habersiz kitleleri de harekete geçirip, krizin derinleşmesine neden olduğu yorumlarına sebep olmuştur (Akşam, 2 Ocak 2012). Yaşanılan bu kriz sürecinin sonunda Borusan üst düzey yetkilileri bir basın toplantısı düzenlemiş ve marka müdürü Bayülgen'in istifa ettiğini bildirip, yaşanılanlardan dolayı tekrar özür dilemişlerdir (Sabah, 28 Ocak 2012). Bu krize marka yönetimi tarafından alınan kararlar ve tutumlar yol açmıştır. Bu açıdan markalar faaliyette bulundukları coğrafyadaki din, dil, ırk, siyasi vb. konulara çok hassas olmalı ve bu noktaları kriz iletişim planlamalarında esas almalıdır. Bu esasları görmezden gelmek markanın yaşadığı kriz sürecini çok daha kötü hale getirebilmektedir. Pınar markasının yönetim kurulu başkanı Selim Yaşar 2017 Anayasa seçimlerinden sonra sponsoru olduğu Karşıyaka Spor Kulübü’nün bölgesindeki seçim sonuçları ile ilgili siyasi tweet atmış, bunun sonucunda Pınar karşıtı bir boykot kampanyası başlatılmıştır (Sputnik, 19 Nisan 2017). Karşıya kaldığı boykot neticesinde "satışlarında \%25 düşüş yaşayan marka indirim kararı alıp, sponsorluğunu gerçekleştirdiği sendika ve kulüple çözüme ulaşması neticesinde" boykotu en az zararla atlatmayı sağlamıştır (Aydın, 2019, s. 1182).

\section{Markaların Sosyal Aracılı Krizlerle Mücadelesi}

Kriz bir markanın finansal durumuna, müşterileri ile arasındaki ilişkiye, markanın itibarına zarar verebilen ve önceden tahmin edilemeyen olaylar bütününü ifade eder (Coombs ve Holladay, 2010; Akdağ ve Taşdemir, 2006). Belirsizlik markayı tehdit eden bir dönem olduğundan yalnızca markanın değil, markanın ortak hareket ettiği veya içinde bulunduğu çevreyi de etkiler (Öztürk, 2010). Kriz iletişimi, kriz durumunda, markanın yapacağı stratejik hamleler ve çeşitli iletişim çalışmalarıdır. Ivy Lee'nin kriz iletişimi deklerasyonundan bu yana kurumun kamuyu ve hedef kitleyi bilgilendirmesinin kriz yönetimi açısından önemi iletişim tartışmalarında ön planda tutulmaktadır (Wheeler, 2019). Olağandışı bir süreç olduğu için alınacak kararlar ve yapılacak 
çalışmalar marka için hayati önem taşımaktadır (Çetin ve Toprak, 2016; Yenice, Pirtini ve Ataman 2018). Kriz iletişiminin temel amacı, kriz anından markayı en iyi şekilde yönetmek olduğu için Heide ve Simonsson'a (2014) göre "ìi bir kriz iletişim stratejisi kriz planından daha önemli olabilmektedir" (aktaran Çelebi ve Sezer, 2017, s. 121). Bir organizasyonun acil tepki verebilmesini gerektiren bir durum veya kaos (Cornelissen, 2019) olarak ifade edilen bu dönem, markanın yaşam döngüsü alanına bağlı olarak ön görülebilir bir problem veya krizin boyut ve oluşma şekline göre anlık aksiyon planları gerektiren bir olgu da olabilmektedir.

Yaşanan ve olası krizler, kaynaklandığı olguya bağlı olarak içsel ve dışsal şeklinde sınıflandırılmaktadır. İçsel krizler, kurumdan veya kurum tarafından gerçekleştirilen bir aksiyon nedeniyle oluşan krizlerdir. Pınar markasının yönetim kurulu başkanı Selim Yaşar'ın 2017 senesinde attığı bir tweet sonrası markanın yaşadığı kriz süreci markanın bir aksiyonu sonucu yani içsel kaynaklı krize örnektir (Sputnik,19 Nisan 2017). Dışsal krizler ise, kurum dışından kaynaklı kişiler veya gruplardan ortaya çıkan krizlerdir (Coombs ve Holladay; 1996, Cornelissen, 2004). Peker ve Aytürk (2000)'e göre “Örgütte krize yol açan dış ya da çevresel etkenler, dünyanın ve ülkenin genel yapısı, ülkenin sosyal, siyasal, ekonomik ve güvenlik durumu ve sorunları, teknolojik gelişmeler ve değişmeler, doğal afetler, sosyal patlama ve huzursuzluklar ile uluslararası tehdit ve tehlikeler olarak sıralanabilir "(aktaran Sezgin, 2003, s. 188). Nutella markasının yaşadığı kriz süreci markanın kendi bünyesinde alınan bir aksiyon sonucu değil, marka dışından markayı etkileyecek bir süreç olduğu için dışsal krize örnektir. Kriz iletişim planları yalnızca kriz anını değil, aynı zamanda kriz öncesini kapsayan iletişim planlarıdır. Bir kriz baş göstermeden önce planlanan kriz iletişimine proaktif, kriz anında yapılan çalışmalara ise reaktif kriz iletişimi denmektedir. Peltekoğlu "Proaktif iletişim, neyin ters gittiğini ya da bir şeyin neden yapıldı̆̆ını açıklamak yerine, önceden planlanmış bir sürecin uyarlanmasıdır. Reaktif iletişimde ise fırsatlardan çok çözüm bekleyen sorunlar, atak önlemler yerine savunmacı yaklaşımlar vardır" (2016, s. 90) şeklinde ifade etmektedir. Kriz döneminde markanın geleceğine etki edecek en önemli yönetsel fonksiyon iletişimsel yanıttır. Krize verilecek yanıtlar ve iletişim yaklaşımları ile ilgili birçok görüş bulunmaktadır. Benoit (1997) "imaj restorasyonu için bu sürecteki tepkileri, sorumluluktan kaçma, eylemlerin olumsuzluklarını azaltma, düzeltme ve kabullenme aşamalarına" bölümlemektedir (aktaran Çetin ve Toprak, 2016, s. 59). Kriz durumuna bir şirketin veya markanın vereceği tepki konusunda ise "Ne olursa olsun, bir şirketin bu eylemden sorumlu olduğuna inanılmadıkça olumsuz bir izlenim oluşturmanın mantıkı" olmadığını belirterek hedef kitlenin algısının önemine değinmektedir (Benoit, 1997, s. 178). İmaj Restorasyonu Kuramı, hedef kitlenin kriz algısının verilecek kurumsal yanıt açısından belirleyici olduğunu ve krizden marka direk sorumlu olmasa bile eğer hedef kitlesi markayı sorumlu tutuyor ise riski yönetmek için markanın gerekli iletişimi gerçekleştirmesi gerektiğini savunur (Benoit, 2997, s. 178). Bu noktada kurama göre bunun sağlamanın yolu, yetkin bir kriz iletişimi ekibi tarafından hedef kitle ile iletişim kurarak doğru bilginin aktarımının sağlanması ve yanlış bilginin dolaşmasının engellenmesidir (Benoit, 1997, s. 179). Coombs da benzer şekilde krizi "Algısal bir iletişim süreci olarak tarif eder" ve bu noktada paydaşların algısının belirleyici olduğunu savunur $(2012$, s. 3). Teoriye göre, kriz 


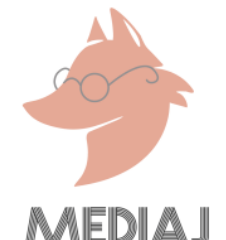

dönemlerindeki bu aşamalardaki algısal yaklaşım, paydaş veya hedef kitlelerin bakış açısında belirleyici olabilir ve marka ile hedef kitlesi arasındaki iletişimi tehdit eder nitelikler barındırabilir (Coombs, 2007).

Sosyal medyanın iletişimsel dinamiği, paydaşların iletişim katmanlarında daha aktif etkiye sahip olmalarını beraberinde getirmektedir. Sınırsız paylaşım ve yorumun bulunduğu sosyal medyada bazen marka, bazen tüketici kaynaklı iletişimsel krizler yaşanabilmektedir. Tüketiciler ile iletişim kurma ve yayılma hızıyla sosyal medyada krizin çok çabuk büyüyebilmesinden dolayı markaların sosyal medya için mutlaka ayrı bir planı olmalıdır. Bilgi akışı bir başka deyişle enformasyon akışı iletişimsel kaynaklı krizlerin şiddetindeki en önemli belirleyicidir. Zira, McLuhan'ın teorilerinde açıkça ortaya koyduğu gibi enformasyon iletişim çevresini araca dönüştürürken, bireyleri yani kullanıcıları da dönüştürmektedir. Olumsuz enformasyon akışını kontrolsüz bırakmak, markaya dair iletişim çevresindeki olumlu ve olumsuz görüş akışının olumsuza yönelmesine izin vermek anlamına gelebilmektedir. Bu nedenle sosyal medya kaynaklı iletişimsel krizlerde iletişim uzmanlarını bekleyen yeni bir iletişim öğesi olarak sosyal iletişim ekolojisinin yönetimi ihtiyacı ortaya çıkmaktadır. Bu durum sosyal medyanın markalar açısından krizlere karşı sorumluluk görüşünü de değiştirmekte ve bu krizlere karşı stratejik tutumun yetersiz kalmasına yol açabilmektedir. Yenice'ye göre "internette marka hakkında yer alan iyi içerikler, şirket hakkındaki olumlu bilgileri desteklerken olumsuz bilgileri de tepki hızına bağlı olarak önleyebilir. Online itibar yönetimi, internette yer alan olumsuz bilgileri silmeye çalışmaz, bu bilgilerin kullanıcılar üzerindeki etkisini azaltmaya ve sorunun kaynağını çözmeye dayanır" (2017, s. 3). Sosyal medya krizlerini önlemenin en temel yolu, krize fırsat tanımadan, sosyal medyada dinleme yaparak marka için gerekli adımları atmaktır. Örneğin, Puerto Rico'da yaşanan kasırga olayından sonra Facebook, kullanıcılarına olay yerini ve insanların uğradıkları yıkımı göstermek için Spaces VR uygulamasını kullanıp, bu uygulama için 'büyülü yolculuk 'tarifi yapmıştır. Bu paylaşımı tepki çekse de marka etkin geribildirim adımları atarak, krizi çözmekte zorlanmamıştır (Ahmed, 2017). Bu noktada çok katmanlı hedef kitlelerin hassasiyetini ölçümleyebilmek ve önceden iletişim etkisi konusunda değerlendirme yapabilmek önem kazanmaktadır. Örneğin günümüzde ırkçılık, ayrımcılık veya toplumsal eşitlik gibi konularda insanlar daha duyarlı olduğu için markalar bu konulara çok daha fazla önem vermektedirler. H\&M markasının diğer markaların konu ile ilgili yaşadıkları krizler ortada iken ve markanın kendisi de daha önce iş̧̧i ücretleri ile ilgili bir kriz yaşamışken, siyahi bir çocuğun üzerinde tanıttığı giyside ormandaki en havalı maymun yazısı olması markanın bir krizi daha yaşamasını kaçınılmaz hale getirmiştir (Üçhisarlı, 8 Ocak 2018). Markanın pazarlama iletişimi görseli kısa sürede sosyal medyada kartopu etkisiyle negatif algı yaratmış ve büyük bir tepkiye dönüşmüştür. Bu sosyal medya aracılı kriz sonrasında, marka kamuoyundan özür dileyerek içeriği geri çekse de, hisseleri ilk çeyrekte \%16 düşüş göstermiştir (Ogisi, 2018). Günümüzde iletişim krizleri, yalnızca bir ürünün satışını değil, eş zamanlı ve hatta uzun vadeli olarak markanın finansal değerini de değiştirebilmekte, birkaç gün içerisinde yaşanan bir sosyal medya krizi, markanın gelecek adımlarında belirleyici olabilmektedir. 


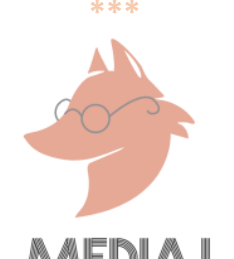

Gelişen kriz durumları, kriz iletişim teorilerini yeni şartlara uyarlama ve farklı faktörlerin yeni araştırma yöntemleri ile sınanması intiyacını beraberinde getirmektedir (Hughes ve Palen,2009; Schwarz, 2016). Kriz iletişimi araştırmaları alanında geliştirilen en yeni paradigma vaka analizi paradigmasıdır (Coombs, 2007). Sosyal medyanın hızlı gelişimi ve araştırma bilimindeki teknolojik yenilikler, sosyal dinleme ve izleme yöntemleri ile elde edilen bulgular, kriz iletişimi yönetimine önemli katkılar sağlamaktadır (Young, Simmons ve Stewart, 2019). Bu alanda yapılan çalışmalar, krizde paydaşların ve hedef kitlelerin bilişsel düzeydeki algısının markaya dair tüm davranışları etkileyici bir faktör olduğunu göstermektedir (Bundy,Praferer, Short ve Coombs, 2016). Buradan yola çıkarak, çalışmanın amacı, sosyal medya aracılı krizleri, örnek vaka analizi yardımıyla iletişimsel etkileşim ve tepki açısından anlayabilmektir. Çalışmada örnek markaya tepki olarak yöneltilen sosyal medya kaynaklı iletişim krizi, Durumsal Krizi Iletişimi Teorisi'nden (Situational Crisis Communication Theory -SCCT) yola çıkarak incelenmektedir.

\section{Durumsal Kriz Iletişimi Teorisi}

Geçmişte markaya yönelik olumsuz tutumun oluşmasında iletişim mecraları kökenli krizler daha geri planda ve reaktif yönetilebilir bir sıralamada yer alırken, sosyal medyanın kamusal alandaki aktif gücü markaların paydaşlar tarafından krizden en çok sorumlu tuttuldukları krizlere dönüşmüştür. Coombs ve Holloway tarafından geliştirilen Durumsal Kriz Iletişimi (SCCT) Teorisine göre, krizin temel iki bileşeni krizin ve itibarın geçmişidir. Coombs (2007), hedef kitle tarafından markanın neredeyse sorumlu tutulduğu ve hedef kitlenin markaya yönelik olumsuz tutumunu tepkisiyle ortaya koyduğu kriz tipini ön görülebilir ve önlenebilir krizler olarak tarif eder. Bu, kriz bileşenleri kapsamında etkili iletişimin sağlanması için bir kriz durumunun özelliklerinin dikkate alınması gerektiği anlamına gelir. Krizler, bir firma ile paydaşları arasındaki daha büyük ve sürekli bir ilişkiye katmanlar ekler. İlk dakikadan son ana kadar süreç içerisinde krizin şiddeti ve marka itibarının tonu krize yaklaşımda belirleyicidir.

SCCT ağırıklı olarak kriz araştırmaları çalışmalarında kullanılan ve Coombs ile Holloway (2010) tarafından durumsal olarak kriz, krizde markanın iletişimsel döngüsü ve paydaş algısını belirlemek noktasından yola çıkarak adapte edilmiş bir yaklaşımdır. Durumsal kriz iletişimi teorisi kriz türlerinin tamamen paydaşların veya başka bir deyişle hedef kitlenin algısının psikolojik boyutu ile belirlenmesi gerektiğini öne sürmektedir. Her kriz durumu, kendi yarattığı algısal hasar ile ele alınmalıdır. Bunun temel nedeni, hedef kitlenin markayı ne derece krizden sorumlu tuttuğunun belirlenmesi ve bu yönde bir davranışsal kriz yönetimi tutumu geliştirilebilmesidir (Coombs ve Hollaway, 2012). Coombs (2010) krizleri, hedef kitlenin krizle ilgili bilişsel algısının markayla ne derece örtüştüğüne göre ayrıştırmaktadır.

Coombs'un sınıflandırmasına göre eğer hedef kitle krizden markayı dolaylı olarak sorumlu tutuyorsa, bu durumda marka bu krizde kurban rolünde algılanır. Afetler, ani kazalar gibi markanın operasyonu dışında gelişen krizler bu grupta yer almaktadır.Eğer paydaşlar krizden 


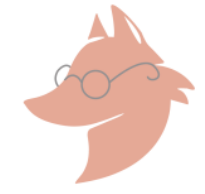

\section{MEIDIAJ}

markayı kısmen sorumlu tutuyorlar ise bu durum orta ölçekli ve yine kısmen planlanabilir krizler olarak sınıflandırılmaktadır. Kriz ile ilgili olarak paydaş tarafından markanın sorumlu tutulması ise önlenebilir ve ciddi ölçekli krizler olarak tanımlanmaktadır (Coombs ve Hollaway, 2012).

Sosyal medya, yapısı itibarı ile birçok farklı unsurun etkileşimi neticesinde tepkinin oluşmasına yol açan ağlardan oluşmaktadır. Bu açıdan bakıldığında son yıllarda markaların sosyal medya tepkisi ile karşılaştıkları krizler, ön görülebilir kriz sınıfında ele alınmalıdır. Krizin hikayesi ve gelişimsel sürecinin analizi, krizin başlangıç anından tepkiye dönüştüğü süreçteki etkileşim ve paydaşların birbirleri üzerindeki etkisinde de belirleyicidir. Durumsal Kriz İletişimi Teorisi kriz tipini anlamak açısından benzer krizleri takip etmenin önemli olduğunu ve bu analizlerin bir ön görebilme pratiği ve hazırlanma imkânı sunduğunu ortaya koymaktadır. Örneğin H\&M ve Nutella'nın yaşadığı kriz pratiği Starbucks ve Nike gibi sonrasında sosyal medyadan farklı iletişim tercihleri nedeniyle tepki alan markalara yol gösterici nitelikte olmuştur. Sosyal medyaya dair krizlerin takip edilmesi neticesinde başlatılan sosyal dinleme ve izleme yöntemleri sayesinde tepkiyi hızla analiz eden Starbucks ve Nike markaları on iki saatten kısa bir sürede krize direnç oluşturma imkânını yakalamışlardır (Heiken, 22 Mart 2019). Eş zamanlı krizsel tepkiyi yönetimsel (real time crisis response) olarak kavramlaştırılan bu örgütsel aksiyonun oluşmasında, yaşanan diğer krizlerin ilham kaynağı olması kadar bu yönde bir krizin tırmanmasını tetikleyen tepkileri ve iletişim trafiğini anlamak yol gösterici nitelikte olabilmektedir.

Kriz iletişimini, kriz öncesi, kriz anı ve kriz sonrası olmak üzere üç aşamada ele alan Coombs (2010) "her bir aşamanın kendine özgü bilgi ihtiyacı yarattığını ve iletişim unsurunun da bu ihtiyacı karşılamak üzere farklı aşamalarda farklı fonksiyonlar üstlendiğini ileri sürmektedir" (aktaran Akbulut,2016, s. 53). Durumsal Kriz İletişimi Yaklaşımı kriz öncesi evreyi iki parçaya ayrılmaktadır. Bunlar önleme ve hazırlık aşamalarıdır. Önleme aşaması, risk oluşturabilecek koşul ve durumları tespit ve analiz ederek bunları ortadan kaldırmayı hedeflemektedir. Sosyal dinleme ve izleme yöntemleri sayesinde krize ne şekilde tepki verileceği ve direnç oluşturulacağı belirlenebilir (Young ve Simmons, 2019). Hazırlık aşaması ise mevcut bir krizde iletişimsel stratejilerinin türünü ve yöntemlerinin belirlenmesini içermektedir (Akbulut, 2016). Bu doğrultuda, bu çalışmanın analiz kısmı için yargısal örnekleme yöntemi ile elde edilen veriler ile sosyal izleme yapılarak toplanmış ve SCCT yaklaşımı çerçevesinde kriz öncesi, kriz anı ve kriz sonrası evrelere göre ele alınmıştır.

\section{ANALIZ KAPSAMI VE YÖNTEMI}

Mikroblog sitesi Twitter, 2020 verilerine göre 340 milyon kullanıcısıyla (We are social, 2020) politikadan spora gündemin oluşmasında etkili olan sosyal ağlar arasında yer almaktadır. Gündem yaratmadaki etkisi nedeniyle örnek vaka kapsamında sosyal izleme yapılabilecek bir sosyal medya platformu olarak tercih edilmiştir. Sosyal izleme Bredeva tarafından "sosyal 


\section{MEDIAJ}

medyada bir içeriği arama, veri toplama ve bireysel sözlerle etkileşim kurma süreci" olarak tarif edilmektedir (26 Ağustos, 2019, parag1.). Çalışmada, Procter \& Gamble firmasına ait olan Fairy markasının reklam yüzü Berna Laçin'in paylaşımları nedeniyle 24 Ocak 2020 tarihinde karşı karşıya kaldığı sosyal medya temelli kriz örnek vaka olarak ele alınmıştır. Markanın karşı karşıya kaldığı boykot sürecindeki iletişim döngüsünü incelemek, bu boykot süresince tüketici ve paydaşlar arasında nasıl etkileşim ve markaya karşı nasıl tepkiler oluştuğunu kriz evreleri açısından ele alabilmek amacıyla MaxQda programı yardımıyla eş zamanlı olarak Twitter üzerinden veri toplanmıştır. Elde edilen verilerin etkileşim açısından dağılımı yine aynı programda analiz edilmiştir. Çalışma kapsamında 24 Ocak-31 Ocak 2020 tarihleri arasında yargısal örnekleme yöntemi kullanılarak elde edilen ve Twitter'da öne çıkan konular arasında gündeme yerleşen Fairy boykotu altında paylaşılan toplam $(n=146)$ paylaşım ele alınarak analiz edilmiştir. Çalışma niceliksel veriler ve yöntemler içermemesi açısından sınırlıdır.

\section{Analiz Bulguları}

Fairy markasının reklam yüzü Berna Laçin'in "hop güncelleme 6.5... Biliyorsunuz bir dereceden sonra o ilde vergi falan depremden dolayı muafiyet alıyor" (Tezel, 28 Ocak,2020) şeklindeki Twitter paylaşımı nedeniyle 24 Ocak 2020'de başlayan sosyal medya kullanıcıları temelli boykot sürecinde marka ve Berna Laçin hakkında atılan 146 içerik analiz için toplanmıştır.

Toplanan veriler metin analizi ile beş kategoride sınıflanmaktadır. İlki, Berna Laçin'e yönelik saldırıları içeren verilerden oluşmaktadır. İkinci kategoride verilerin büyük çoğunluğunu oluşturan markayı ve Laçin'i boykot edeceğini söyleyen içerikler yer almaktadır. Üçüncü kategoride, deprem ile ilgili atılan tweet sonrası Berna Laçin'in herhangi bir hatası olmadığını düşünen fakat markanın Laçin ile olan sözleşmesini iptal ettiği iddiaları yüzünden markayı boykot edeceğini ifade eden paylaşımlar yer alırken, dördüncü kategoride yaşanan bu kriz sürecinde herhangi bir boykot uygulamayacağını, tam tersine marka ve Laçin'e desteğini belirten içerikler bulunmaktadır. Son kategoride ise boykotu marka özelinde ele alan ve ana akım medyanın paylaşımlarında markayı boykota davet ettiği içerikler yer almaktadır. Bu veriler ışığında paylaşımların, birbirleri ve süreç üzerindeki etkileri, hangi tetiklemelerle ve nasıl oluştuğunun incelenmesi hedeflenmiş ve teorik yaklaşım doğrultusunda süreçsel olarak düzenlenerek gözlemlenmiştir.

Kriz iletişimi araştırmalarında süreçsel gelişimi ayırt etmek için SCCT yaklaşımı, kriz öncesi, kriz anı ve kriz sonrası süreçler olarak ayrıştırmaktadır. Bu sayede krizin henüz filizlenmeye başladığı anlardan itibaren hedef kitlenin tepkisini dinlemek ve iletişime geçmek mümkün olabilmekte, kriz riski yönetilebilmektedir (Coomsb, 2007). Ocak ayında gerçekleşen Elazığ depremi sonrasında Berna Laçin'in Twitter paylaşımı ile başlayan, Fairy markasına yönelik bir tepkiye dönüşen \#FairyBoykot krizi, kriz öncesi, kriz anı ve kriz sonrası olarak analiz için sınıflandırılmıştır. Durumsal kriz iletişimi teorisi, krizin süreçsel perspektifinin çıkarılmasında, tetikleyici olayın belirlenmesinin sürecin ve diğer tetiklerin tanımlanması açısından ilk yapılması gereken analiz olduğunu belirtmektedir (Coombs, 2007). 


\section{MEIDIAJ}

Elazığ depreminin gerçekleşmesinden kısa bir süre sonra marka sesi olarak uzun yıllardır tüketici karşısına geçerek Fairy adı ile paydaşlara seslenen Berna Laçin'in attığı tweete verilen ilk negatif tepkiler kriz öncesi evre olarak belirlenebilir. SCCT'ye göre, olumsuz durum daha krize dönüşmeden "ilk tepkisel mesajlara, paydaşlara olumsuz bir tepkiye ve medyada markaya karşı oluşacak olumsuz bir bakışa direnç oluşturmak için potansiyel ipuçlarını vermektedir" (Coombs \& Holladay, 2010, s. 26). Fairy krizinde ise ilk tepkinin ipuçları Berna Laçin'e yönelik paylaşılan \#BernaLaçinBoykot etiketi altında gözükmekte, henüz tepki Fairy adına yönelmeden, Laçin'e yönelik Twitter paylaşımlarında Fairy adının geçtiği olumsuz tepkiler gözlemlenmektedir (Tablo1.-Örnek1).

Durumsal kriz iletişim teorisi, ilk tepkinin duygusal yansımasının, krizin gidişatında genel algının ne yönde olacağının belirleyicisi olduğunun altını çizer. Bu yönde ilk tepkilerin kızgınlık, üzüntü, suçlama gibi duygularda yoğunlaşması negatif bir algı oluşacağının habercisidir (Coombs, 2007). Berna Laçin'e yönelik olarak başlayan sosyal medya tepkisinin ilk izlerinde öfke gözlemlenmekte ve bazı paylaşımlara öfke ile birlikte Fairy markası da dolaylı olarak dahil edilmektedir. Bu tepki durumsal olarak hedef kitlenin Laçin'in iletisinden sonra sessiz kalan Fairy markasını, iletişimsel süreç açısından krizden sorumlu tuttuğu ilk an olduğunu düşündürmektedir (Tablo1., Örnek 1). Berna Laçin'in dolaşıma giren tweetinden kısa bir süre sonra Türkiye geneli trend başlıkları arasına giren \#BernaLaçinBoykot etiketini kısa süre sonra \#Fairyboykot etiketi takip etmeye başlamıştır.

Tablo 1. Kriz öncesi evre paylaşım tablosu

\begin{tabular}{|c|c|c|}
\hline \multirow{3}{*}{ \#FairyBoykot } & Örnek 1 & $\begin{array}{l}\text { Berna Laçin"in reklamını yaptığı bulaşık deterjanını almayın Cem } \\
\text { Yılmaz"a nasıl boykot yapıldı Fairy" e de yapılsın bak bakalım bir daha } \\
\text { bu kadını reklamında oynatıyor mu }\end{array}$ \\
\hline & Örnek 2 & $\begin{array}{l}\text { \#BernaLacinBoykot Berna gider baskasi reklam yapabilir ama ya marka } \\
\text { itibariniz o biterse bitersiniz . \#bernalacinigörmekistemiyoruz .Sözlesmeni } \\
\text { fesh et @mutlumutfaklar }\end{array}$ \\
\hline & Örnek 3 & $\begin{array}{l}\text { Ben reklamında oynadığı için zaten fairy kullanmıyorum. O oynadığı } \\
\text { müddetçe de kullanmayacağım. Kullananlari da uyarmaya devam } \\
\text { edeceğim. Biz bunları milletini vatanini sevenler bilirdik. İnsanır farklı } \\
\text { düşünür farklı partiye oy verir ama böyle zamanda birlik olur } \\
\text { \#fairyboykot }\end{array}$ \\
\hline
\end{tabular}

İlk etkileşimler ve Laçin'e tepki, Choi ve Lin'in (2009) belirttiği gibi tepkilerin hangi duygu yönünde gelişeceğinin belirleyici göstergesidir. Reklam yüzünün paylaşımına yönelik ilk tepkilerle birlikte şiddetlenmeye başlayan boykot, marka açısından güçlü bir negatif algının dolaşımda olduğunu ve markanın sessizliğinden dolayı kullanıcılar tarafından sorumlu tuttulduğunu ( $n=146)$ tweetin ( $n=134)^{\prime}$ ünün bu yönde olmasıyla göstermiştir. Dolaşımdaki ilk tweetlerin çoğu markanın bu tepkiye sessiz kalmasını eleştirmiş, bazıları ise bu konu hakkında markayı sorumlu tutarak markadan bekledikleri aksiyonsel tepkiyi paylaşmıştır. Bu 


\section{MEDIAJ}

paylaşımların çoğu Laçin'in iletisi nedeniyle hedef kitlenin bir daha markayı satın almama yönünde bir eğilime sahip olduklarını göstermektedir (Tablo1., Örnek 2). Bazı paylaşımlar ise bu tepkinin dolaşımda perçinlenmesini destekler nitelikte ve kriz öncesinde markaya yönelik olumsuz algıyı içeren şekildedir (Tablo1., Örnek3).

Coombs ve Holladay (2010), krize verilen tepkilerde, paydaşların hangi kaynakları kullandığını anlamanın kaynakları stratejilendirmek açısından analiz unsurlarından biri olduğunu öne sürer. Özellikle iletişimsel krizler üzerine yapılan son dönem çalışmalar, aracın ne şekilde kullanıldığını anlamak açısından önemli olduğunu ortaya koymaktadır (Hughes ve Palen; 2009; Cheng, 2016). 24 Ocak 2020 tarihinde paylaşılan twitlerin ve boykotun Fairy'e yönelten etkileşimin ağırlıklı olarak (\%95) masaüstü kullanımlardan dolaşıma geçtiği gözlemlenmiştir (Tablo 2.). Buna karşın yüzde beş oranında android cihaz kullanımı olmuştur.

Tablo 2. Kriz anı evresi etkileşim veri tablosu

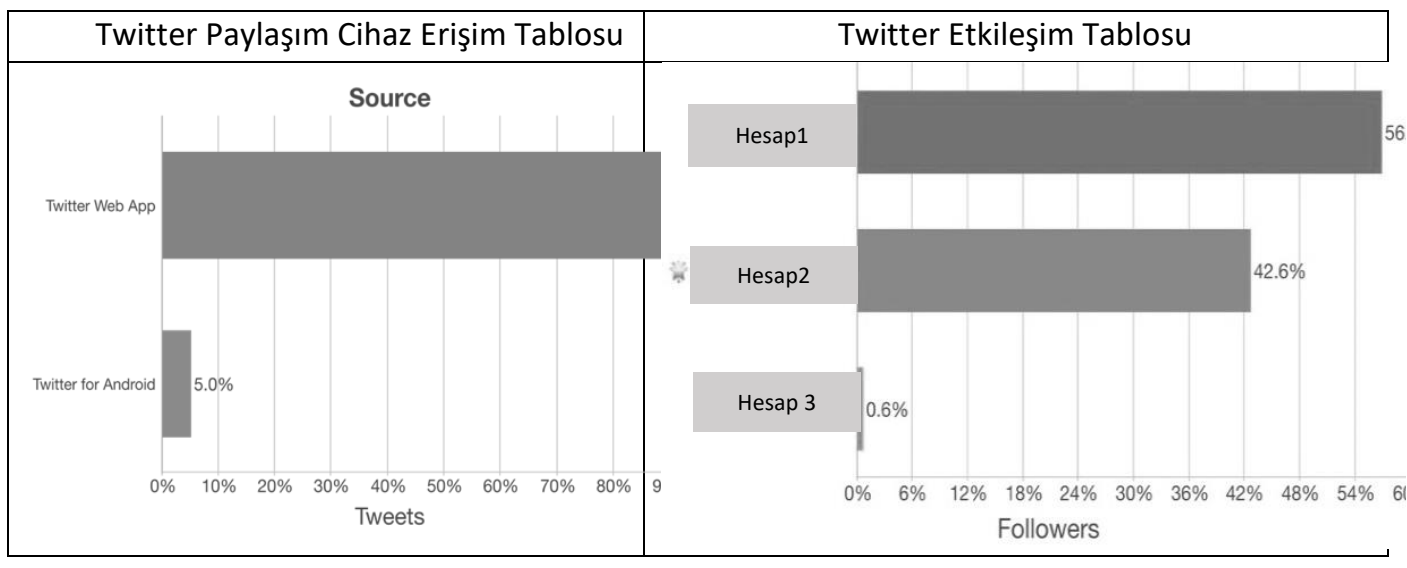

Krizin yükselen trendler arasına girdiği süreç kriz anı evresi olarak temel alınmıştır.Bu evrede içeriklerde, Fairy'den Laçin ile sözleşmesini feshetmesi, yollarını ayırması beklentisi gözlemlenmektedir (Tablo 3., Örnek 4). Bu grubun markayı satın almaktan vazgeçeceğini duyuranlardan farklı olarak Fairy'den bir tepki beklentisi içerisinde olması markanın kullanıııarının oluşan kartopu etkisiyle karşı karşıya kaldıkları duygusal çelişkiyi işaret etmektedir. Bunun yanı sıra paylaşımların çoğunda hedef kitle Fairy'den bu yönde bir açıklama beklendiğini ifade etmekte, bazıları ise markanın sessiz kalması ile geçen sürece dikkat çekmektedir (Tablo 3., Örnek 4). Savcılık tarafından bu konuda soruşturma açılması krizin şiddetlenmesinde etkili olan bir diğer olay olmuştur. Geçen süreçte paylaşımlarda Fairy görselleri yer almaya başlamış ve marka itibarı açısından kalıcı etki yaratabilecek negatif içerikler dolaşıma girmiştir (Tablo 3., Örnek 5). Kriz öncesi evreye kıyasla paylaşılan metinlerin duyusal yönüne bakıldığında tepkinin öfkeye dönüştüŭü, 'vatan haini', 'provakatör' gibi söylemlerin baskın hale geldiği, markanın menşei ile ilgili olarak 'yahudi' ifadesiyle ötekileştirmenin dolaşıma sokulduğu ve bu tema ile nefret söyleminin tetiklendiği gözlemlenmiştir. 


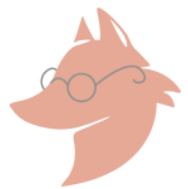

\section{MEIDIAJ}

Coombs ve Holladay (1996), sessizlik stratejisi uygulanmasının durumun yönetimi açısından olumlu sonuç vereceği krizleri, marka dışından kaynaklanan ve hedef kitle tarafından markanın kurban olarak nitelendirildiği, bu nedenle birincil sorumlular arasında tutulmadığı krizler olarak tarif etmektedir. Oysa \#Fairboykot etiketiyle tırmanan bu krizdeki tepkiler incelendiğinde paylaşımların önemli bir bölümü tarafından markanın duruşuyla krizden sorumlu tutulanlar arasında değerlendirildiği ve bilgilendirme talep ettiği gözlemlenmektedir (Tablo 3., Örnek 4). Fairy'nin kriz öncesi evreden itibaren konu ile ilgili herhangi bir iletişimde bulunmaması, olumsuz tepkilerin ve kızgınlığın markaya yönelmesinde etkili olduğunu düşündürmektedir.

Tablo 3. Kriz anı evresi paylaşım tablosu I

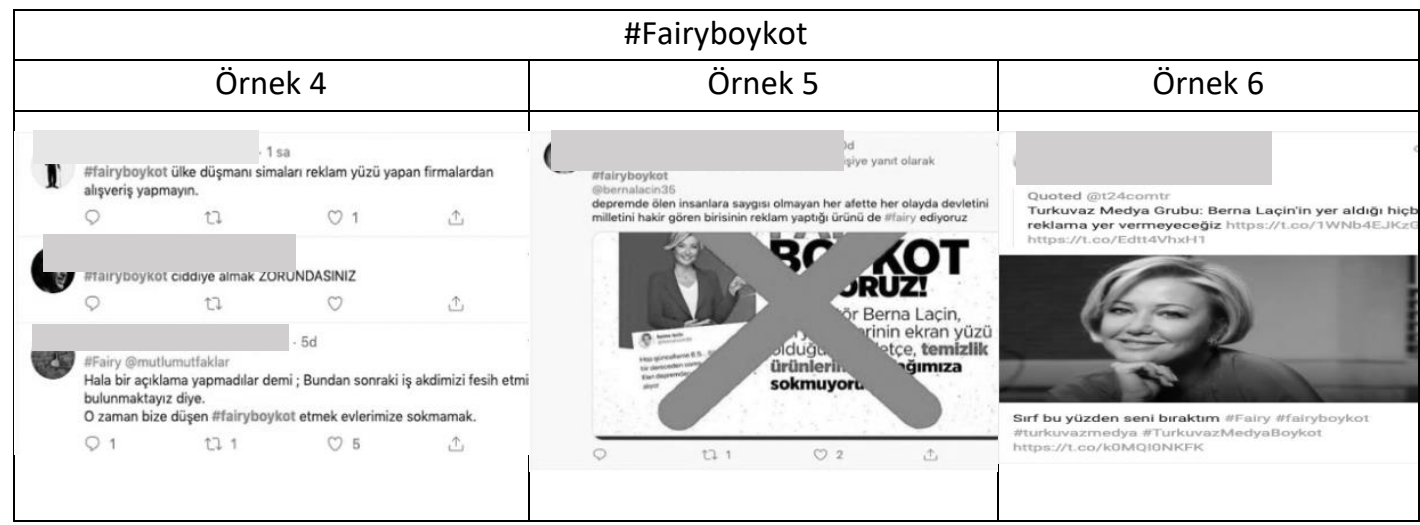

Cova ve D'Antone (2016), Nutella palm yağı krizine tepkileri inceledikleri çalışmada tepkisel büyümedeki en etkili aktörlerin önemine işaret etmektedirler. Sosyal medya ağlarında birçok mikro topluluğun ortak etkileyicisi konumundaki hesapların paylaşımlarının krizin iletişimsel olarak tırmanmasında etkili olduklarını göstermektedir (Durfee, 2019). Bu aşamada duruma karşı hedef kitlenin tepkisini tetikleyebilecek toplulukların anlaşılması, krizin hangi odaklardan yönetilebileceğini ön görebilmek açısından oldukça önemlidir. Fairboykot etiketi altında oluşan etkileşimde yüksek etkileşimli hesaplar, sosyal izleme yöntemi kullanılarak belirlenmiş ve elde edilen veriler Tablo 2.'de paylaşılmıştır. Buna göre Tablo 2.'de verilen görünürlük grafiğindeki hesap1 \%56,9 ile en çok etkileşimi olan hesaptır. Onu \%42,6 ile yine aynı tabloda verilen hesap 2 takip etmiştir. \%0,6 etki oranı ile hesap 3 ise yüksek etkileşimli hesaplar arasında üçüncü sıradadır. Paylaşımların yarattığı etki ile konunun görünür olması kanaat önderlerinin dikkatini çekmesine yol açtığı gözlemlenmiştir. Bunu takiben @hilalkaplan ve @yeniakit hesaplarında bu ilk tepki habere dönüşerek yer almış ve paylaşımıştır. Bu etki ile konu ana akım medyanın gündeminde yer almaya başlamış ve bazı medya kuruluşları Fairy reklamlarını yayınlamayacaklarını duyurmuşlardır (Tablo 3., Örnek 6).

Ana akım medyanın tepkisinin paydaş olarak krize dahil olması krizin şiddeti ve hedef kitle tepkisi artmıştır. Gündüz kuşağındaki programları sunan ünlüler tarafından Laçin ile birlikte markaya tepki dile getirilmeye başlanmıştır. Kriz anı evresinde marka dört gün sessiz kalmış, markanın Laçin ile sözleşme iptal ettiği iddiasını içeren yanlış bilgi, bu boykota karşı Berna 


\section{MEDIAJ}

Laçin'i destekleyen grubun da etkileşime dahil olmasına yol açmıştır. Bu süreçte, savcılık soruşturması akabinde markanın kurumsal iletişim başkanı Ayça Turgay’a ait olan bir açıklama yapılmıştır (Cem, 28 Ocak 2020). Sosyal medyada bu açıklama sonrasında reklam sözleşmesinin iptal edildiği bilgisi yayılmaya başlamıştır. Sözleşme iptali ile ilgili yayılan bilginin sosyal medyada tırmanmasıyla Laçin'e destek veren paylaşımlar da krize dahil olmuştur. Twitter üzerinden krizin altıncı gününde Laçin yine Twitter hesabı üzerinden marka ile ilgili birlikteliğinin devam ettiğine dair bir açıklama yapmıştır. Bu açıklama neticesinde boykot etkileşimi hem destekçiler, hem sözleşme iptali isteyenler arasında yoğun tartışmaya yol açmış ve \#fairyboykot etiketi tekrar Twitter Türkiye gündeminde ilk sıralara yükselmiştir. Pazar lideri Fairy markasının sessizlik stratejisi neticesinde söylem "biz ve onlar karşıtlığı" üzerinden nefret söylemine dönüşmüştür (Tablo 4., Örnek 7).

Tablo 4. Kriz anı evresi paylaşım tablosu II

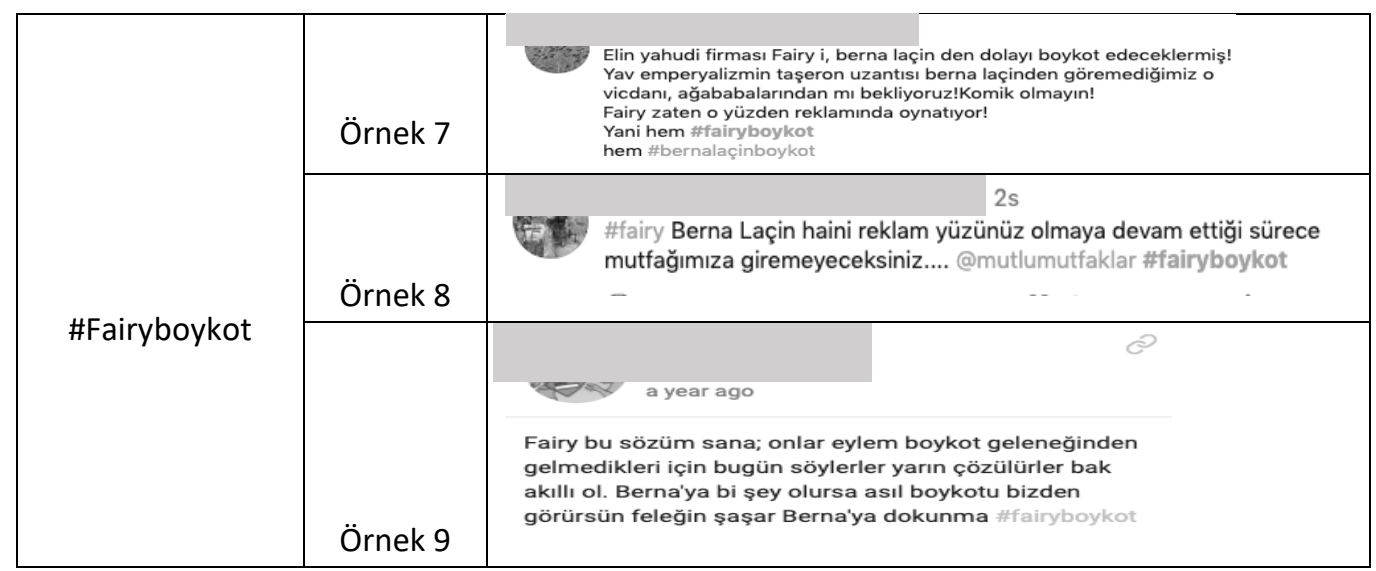

Bu süreci takiben Fairy, Twitter hesaplarından Laçin'in yer aldığı fotoğrafları silmiştir (Yenişafak Gazetesi, 2020). Berna Laçin'in yer aldığı görselleri markanın hesaplarından kaldırması Laçin'in bu duruşunu destekleyen kullanıcıların tepkisine yol açmış ve bu grubun paylaşımları ile krizin farklı bir görüş açısından şiddetlenmesine yol açmıştır (Tablo 4., Örnek 9). Bu tip paylaşımlarda kullanıcıların markayı tehdit eder bir dil ile uyardıkları gözlemlenmektedir. Bu süreçte Laçin'i destekleyen @feyzaaltun ve @sahinmengu gibi bilindik isimler Fairy markasını direk hedef alarak takipçilerini bir daha Fairy markasını kullanmamaya çağırmış ve benzer şekilde bu paylaşımlar da yüksek etkileşimleri nedeniyle ana akım medyada yer bulmuştur (HalkWeb, 19 Ocak 2020). On gün kadar süren krizin sonunda marka bir açıklama yaparak sorumluluğu yurtdışındaki genel merkezine yönlendirmiştir.

Şubatın ilk günleri dahil olmak üzere ana akım medya mecralarının sosyal medya hesaplarından paylaştıkları haberlerde markanın Laçin ile sözleşmesinin iptal edildiğini iddia eden haberlere rastlanmaktadır. Markanın Şubat 2020 döneminde dolaşıma soktuğu yeni reklam kampanyasında Berna Laçin'in yer almasının bu tepkilerin devam etmesine yol açan bir kurumsal aksiyon olduğu düşünülmektedir. Markanın resmi Twitter hesabının kriz süresi 


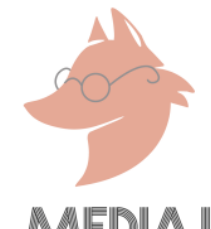

boyunca kapalı tutulması, bu mecrada oluşan olumsuz kriz geçmişini sessizlik stratejisi ile karşıladığını göstermektedir. Kriz anı sonrasında ise konuya yönelik paylaşımlar daha düşük etkileşim oranları ile devam etmiş, bu yönde change.org sistemi üzerinden bir imza kampanyası başlatılmış ve Mayıs 2020 tarihine kadar bu imza kampanyasına 200 civarında kişi tarafından katılım sağlandığı gözlemlenmiştir.

Mayıs 2020 tarihinde holdingin kendi kurumsal iletişim mecralarında yer alan sosyal sorumluluk kampanyasında Laçin'in adının da yer alması, markanın Şubat 2020 tarihinden Laçin ile görünür olmamasına karşın, $P \& G$ Holding faaliyetlerinde yer almaya devam ettiğini ve aksi yönünde yayınlanan haberlere karşın kurumun Laçin ile işbirliğinin devam ettiğini göstermektedir (https://www.pg.com.tr/blogs/umut2020/). Kriz sonrasında markanın, bir orta nokta bulmak amacıyla Laçin ile reklam çalışmalarını iptal ettiği veya ertelediği ön görülmektedir. Marka, geçtiğimiz yaz aylarında gıda alanında gerçekleştirdiği sosyal aktivizim kampanyasında "10 yıldır reklam yüzü olan Berna Laçin'in desteği ile" ifadesine resmi internet sitesinde yer vermektedir. Mayıs 2020 tarihinde holdingin kendi kurumsal iletişim mecralarında yer alan sosyal sorumluluk kampanyasında Laçin'in adının da yer aldığı görülmektedir. Her ne kadar kriz anında ve sonrasında bu kurumsal kararını kriz yaşadığı medya mecralarında duyurarak şeffaf bir iletişim stratejisi geliştirmemiş, bu olaydan beri resmi Twitter hesabını aktifleştirmemiş olsa da Laçin ile çalışmalarına devam ettiği anlaşılmaktadır. Bu durum ileri dönemlerde reklam yüzünden kaynaklanabilecek sosyal medya aracılı krizlerde markayı daha zor duruma sokabilecek bir karar olsa da, Nike'ın yaşadığına benzer şekilde marka savunuculuğuna da dönüşebilir. Ancak yine de markaların sosyal medyadaki kriz süreçlerinde gerek hedef kitlelerle gerek paydaşlarla iki yönlü ve proaktif iletişim yaklaşımı geliştirmesi uzun vadede çevirimiçi platformlardaki imajı ve itibarı açısından önemlidir. Aralık 2020 tarihinde Google aramalarında Fairy ve Berna Laçin isimleri birlikte arandığında çıkan ilk üç sayfada krizin etkilerinin hala baskın olduğu görülmektedir. Bu durum markanın henüz dijital alanlarda krizi tam olarak geride bırakamadığını ve konu hakkında sessizlik stratejisini bu platformlarda devam ettirdiğini düşündürmektedir.

\section{SONUÇ}

Hayatımızın bir parçası haline gelen sosyal medya, geniş kitlelerin kısa sürede etkileşime geçebilmesi, olumsuz içeriklere karşı direnç geliştirmeyi zorlaştıran bir hızla yayılabilmesi gibi yönleriyle markalar açısından krizi yönetmek açısından dezavantaj yaratabilmektedir. Sosyal ağlarda yalnızca markanın görünür olmasını artıracak yaklaşımlar değil, daha görünür olmakla markaların yüzleşebileceği krizlerle ilgili de stratejik iletişim planları geliştirmesi önemli hale gelmiştir. Bir krizin ortaya çıkmasını çok daha kolay hale getiren sosyal aracılı herhangi bir etkileşim oluşmadan önce durum ciddiye alınmalı ve kriz süreçleri de bu alanda yetkin, yeni akım medyanın tabiatına hakim uzmanların önerileri ışığında çözüme kavuşturulmalıdır. Çalışmada bahsedilen birçok başarılı markanın sosyal medya aracılı krizlere gerekli araştırma planı ve risk planı ile hazırıklı yakalandıkları ya da yönetebilecek veriyi analiz edebildikleri 


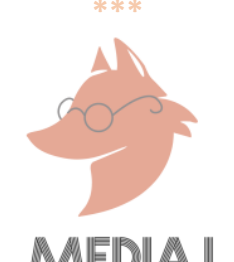

görülmektedir. Sosyal medya kaynaklı krizler, yıllar boyunca bir markanın itibarında olumsuz iz bırakabilecek krizlerdir. Bu açıdan markalar,yaşayabilecekleri olası risk durumlarını yönetebilmek veya en az zararla atlatabilmek için kriz araştırmalarını ve sosyal medya dinleme-izleme araştırmalarını stratejik iletişim planlarına eklemelidirler. Günümüzde Taco Bell, Facebook, Amazon gibi bazı küresel markalar, sosyal medya ve kriz araştırmaları için özel departmanlar yapılandırmakta, veriyi eş zamanlı analiz ederek takip imkânı yakalamaktadırlar. Sosyal izleme, tematik analiz, bölgesel analiz, sentiment ya da duyusal analiz yöntemlerinin iletişimin planlama süreçlerine dahil olması gerekli ön görüyü sağlayabilmektedir. Stratejilerine kriz araştırmalarını eklemleyen markaların, kriz öncesi evrede riski fark etme imkânı yakalayarak kriz iletişimi senaryolarını adapte ederek yanıtladıkları ve krizi en az hasarla atlattıkları görülmektedir. Çalışma kapsamında ele alınan örnek vakada ise, tersine süreç içerisinde markanın hedef kitle tarafından sorumlu tutulmasına yol açabilecek bir sosyal medya saldırısı olmuş, marka bu konuda hedef kitleleri ile sosyal medyada iletişim kurmamış ve marka adına dönen boykot nefret söylemi fırtınasına dönüşmüştür. Yanı sıra markanın sessizliği farklı konularda dezenformasyonun dolaşıma girmesine ve imajında bu tarz çağrışımların yer etmesine yol açmıştır. Markanın hala Berna Laçin ile işbirliğini devam ettirmesine rağmen sosyal medya hesabını kapalı tutması ve kriz yaşadığı mecrada bu konuda şeffaf olmaması, marka açısından krizin ön görülemediğini düşündürmektedir.

Herhangi bir sosyal medya krizi yaşandığında veya sosyal medya üzerinden marka hakkında olumsuz düşünceler paylaşıldığında, markanın yapması gereken paylaşımın üstünü örtmeye çalışmak veya görmezden gelmek değil, sosyal medyaya kulak verip tüketicinin düşüncelerini ve prensiplerini dikkate almaktır. Örnek vakada yaşanan kriz evrelerinde marka hiçbir yetkili isim ile medya karşısına çıkmamış ve bazı gazetelerde kaynağı net olamayan birtakım haberler dışında hiçbir açıklama görülmemiştir. Markanın bu tutumu Berna Laçin'in yaşadığı linç durumunu markaya yönelen bir boykot hareketine evrilmesine engel olamamıştır. Günümüzde birçok markanın sosyal medyada zorlanması, örnek vakada görüldüğü üzere pasif düzeyde iletişimle krizi yönetmeye çalışmasına yol açabilmektedir. Bunun sonucunda oluşan dezenformasyon, marka açısından dijital platformlarda kalıcı imaj ve itibar kayıplarına yol açabilmektedir. Markanın sorumlu tutulduğu benzer krizlerde, hedef kitle ve ana akım medya ile ilişkisini kopartmaması ve gerekli geri bildirimleri aynı mecralar üzerinden zaman kaybetmeksizin gerçekleşmesi örneklerde görüldüğü üzere çok daha proaktif bir yaklaşım benimsemesini sağlayacaktır. Sosyal medya aracılı krizler için markaların kriz öncesi, kriz anı ve kriz sonrasını ön görebilecek ve sosyal medya dinleme becerileri gelişmiş uzman bir iletişim ekibi ile çalışması krizleri yönetebilmesinde daha etkin olmasını sağlayabilecektir. Sessizlik SCCT yaklaşımında da belirtildiği gibi markanın hedef kitle tarafından sorumlu tutulmadığı krizlerde etkin kullanılması gereken bir stratejidir. Krizin şiddetlendiği mecralarda markayı temsilen gerekli medya eğitimlerini almış kurum sözcülerinin ön plana çıkması ve hedef kitlenin beklentisini iletişimsel düzeyde karşılaması önem taşımaktadır. 
Tüketici ve markalar açısından uzun zamandır hayatlarında var olsa dahi sosyal medya, araştırma teknikleri açısından henüz keşfedilen ve veri analizi sayesinde etkin yönetilebilen bir alandır. İletişim ekiplerindeki iletişim araştırmacılarının eksikliği, çoğu iletişim planında olası krizler dışında anlık kriz ve tepki çalışmalarının bulunmayışı, markalar açısından günümüzün en önemli sorunlarından biridir. Bilişim yatırımı ve araştırma donanımına sahip iletişimcilerin marka iletişimi ekiplerine eklenmesi sosyal medya aracılı krizlerle mücadelenin önemli bileşenleridir. İçinde bulunduğumuz dönemde artan dijitalleşme, dijital atak ya da dijital savaş odalarının yapılandırılmasını markalar için kaçınılmaz kılmıştır. Dijital atak ekipleri, anlık medya takibi, sosyal dinleme ve veri analizi yapabilen ve senaryo oluşturarak marka yöneticilerine yol gösteren iletişim ekipleridir. Sosyal medyada iletişimin markalar tarafından bir futbol maçı gibi düşünülmesi ve sessiz kalmanın yalnızca savunmada kalmak olduğunun anlaşılması önemlidir. Zira bu konuda yeterli donanıma sahip markalar savunma yerine hücum stratejileri ile krizleri fırsata dönüştürebilmekte ve çevirim içi itibarlarını koruyabilmektedirler.

\section{KAYNAKÇA}

Aydın, A. F. (2019). Kurumsal markalar açısından kriz iletişiminin önemi: Pınar krizi. Bolu Abant Izzet Baysal Üniversitesi Sosyal Bilimler Enstitüsü Dergisi, 19(4), 1169-1188, doi: 10.11616/basbed.v19i51339.619975.

Ahmed, S. (22 Aralık 2017). 2017'nin en büyük 5 marka hatası. Campaign Türkiye. Erişim adresi: https://www.campaigntr.com/2017nin-en-buyuk-5-marka-hatasi/

Akbulut, E. (2016). Durumsal kriz iletişimi teorisi çerçevesinde örgüt-kamu ilişkisinin ve kriz tepki stratejilerinin sorumluluk atfetme düzeyine ve örgütsel itibar algısına etkileri. Gümüşhane Üniversitesi Iletişim Fakültesi Elektronik Dergisi 4(1), 51-81.

Akdağ, M. ve Taşdemir, E. (2006). Krizden çıkmanın yolları: etkin bir kriz iletişimi. Selçuk Üniversitesi İletişim Fakültesi Akademik Dergisi, 4(2), 141-157, Erişim: www.selcuk.edu.tr

Benoit, W. L. (1997). Image repair discourse and crisis communication. Public Relations Review, 23(2), 177-186, doi: 10.1016/ S0363-8111(97)90023-0.

Bredeva, A. (26 Ağustos 2019). Social media monitoring v.s. listening. Erişim:17 Mart 2021, awario.com

Cem F. (28 Ocak 2020). Berna Laçin için tehlike çanları çalıyor!. Sabah Gazetesi. Erişim: 22 Mayıs 2020, www.sabah.com.tr

Cheng, Y. (2016). How social media is changing crisis communication strategies: Evidence from the updated literature, Journal of Contingencies of Crisis Management, doi: 10.1111/1468-5973.12130. 
Chp'den Berna Laçin'i silen Fairy'i boykot çağrısı. (17 Mart 2021). HalkWeb. Erişim: 18 Mart 2021, https://halkweb.com.tr/

Choi, Y., ve Lin, Y. H. (2009). Consumer responses to Mattel product recalls posted on online bulletin boards: Exploring two types of emotion. Journal of Public Relations Research, 21(2), 198-207, doi: 10.1080/10627260802557506

Coombs, W.T. (1995). Choosing the right words: The development of guidelines for the selection. Management Communication Quarterly, 8, 447-476, doi: 10.1177/0893318995008004003

Coombs T.W. ve Holladay S.J. (1996). Communication and attributions in crisis: an experimental study in crisis communication, Journal of Public Relations Research, 8(4), 279295, doi: 10.1207/s1532754xjprr0804_04

Coombs, T.W. (2007). Protecting organization reputations during a crisis: the development and application of situational crisis communication theory. Corporate Reputation Review, 10(3), 163-176, doi: 10.1057/palgrave.crr.1550049

Coombs, T.W. (2010). Parameters for crisis communication, Timothy Coombs ve Sherry Holladay (ed), içinde, The Handbook of Crisis Communication, (s.17-53). Birleşik Krallık: Malden, MA Wiley Blackwell.

Coombs, T.W. ve Holladay, S.J. (2010). Examining the effects of mutability and framing on perceptions of human error and technical error crises: Implications for situational crisis communication theory, Timothy Coombs ve Sherry Holladay (ed), içinde, The Handbook of Crisis Communication. (s.181-204). Birleşik Krallık: Malden, MA: WileyBlackwell.

Coombs T. W. (2012). Ongoing crisis communication: planning, managing and responding. California: Sage Yayınevi.

Cornelissen J. (2004). Corporate theory and practices. Londra: Sage Yayınevi.

Cornelissen, P. A. (2019). Speaking of safety: the role of communication in managing occupational safety (Doktora tezi). Enschede, University Twente, Erişim adresi: https://research.utwente.nl/en/publications/speaking-of-safety-the-role-of-communication-

\section{in-managing-occupati}

Cova, B. ve D'Antone, S. (2016). Brand iconicity v.s. anti-consumption well-being concerns: the Nutella palm oil conflict. Journal of Consumer Affairs, 50(1), 166-192, doi: 10.1111/joca.12082

Çelebi, E. ve Sezer, N. (2017). Kurumsal itibarın kriz iletişim stratejileri üzerine etkisi. 


\section{MEIDIAJ}

Akdeniz Üniversitesi Iletişim Fakültesi Dergisi, (27), 116-134.

Çetin, M. ve Toprak, Y. E. (2016). Kriz iletişimi ve sosyal medya: Emisyon krizinde Volkswagen'in Facebook kullanımı. Selçuk iletişim Dergisi, (9), 55-57, doi: 10.18094/si.51665

We are Social \& Houtsuite (2020). Digital in 2020. Erişim: 22 Ocak 2020, Erişim adresi https://wearesocial.com/digital-2020

Durfee, A.(2019). Why chatbots should be a part of your crisis communication plan. Forbes, (17 Ekim 2019). Erişim: 25 Aralık 2020, Erişim adresi:https://www.forbes.com.tr

Edelmann (2018). Trust brands barometer social media. Erişim adresi: https://www.edelman.com/research/2018-edelman-trust-barometer

Fairy Berna Laçin'i sildi. (2020, Ocak). Yenişafak Gazetesi. Erişim: 25 Aralık 2020, https://www.yenisafak.com/infografik/fairy-berna-lacini-sildi-14791

Gökmen, F. N. (2008). Kriz iletişimi: Marmara depremi örneği. Selçuk iletişim Dergisi, 5(3), 161-175.

Gökmen, T. M. (t.y) Borusan'ın "Başörtüsü" krizi: toplumsal hassasiyetler medya etkisiyle nasıl kriz doğurur? (Yüksek Lisans Tezi). Galatasaray Üniversitesi, İstanbul.

Heiken, S. (22 Şubat 2019). Nike: a real time lesson in crisis management. Forbes. Erişim: 25 Ocak 2021, Erişim adresi: www.forbes.com.tr

Hughes, A. L., ve Palen, L. (2009). Twitter adoption and use in mass convergence and emergency events. International Journal of Emergency Management, 6(3/4), 248-260, doi: 10.1504/IJEM.2009.031564

internet ve sosyal medya kullanıcı istatistikleri, 2015, Erişim adresi: https://wearesocial.com/

italyan Nutella şirketi kanser iddiaları sonrasında zorda, 2017(Ocak), NTV, Erişim: 28 Ocak 2021, https://www.ntv.com.tr

Kalaycı, B. N. (2017). Sosyal medyada kriz iletişimi; Turkcell örneği. Uluslararası Illetişimde Yeni Yönelimler Konferansı'nda bildiri, İstanbul Ticaret Üniversitesi, İstanbul. Erişim: 21 Nisan 2020, Erişim adresi: http://acikerisim.ticaret.edu.tr/xmlui/

Karşıyaka'da 'Hayır' çıkması üzerine sponsorluğu çekme tehdidi yapan Pınar'ın ürünlerine boykot çağrısı. (2017, Nisan). Sputnik, Erişim: 25 Aralık 2020, www.sputnik.com.tr

Kaya, i. (2019). Kurumsal krizin sosyal medyada yansımalarına yönelik analizi: Turkcell ve 


\section{MEDIAJ}

Ülker örneği. (Doktora Tezi), İstanbul, Marmara Üniversitesi.

Kotler, P. (2010). Yoksulluğa karşı sosyal pazarlama. (Z.Kökkaya, çev.) İstanbul: Mediacat.

Kim, J.K., Overton, H., Bhalla, N. ve Li J.Y. (2019). Nike, Colin Kaepernick, and the politicization of sports: Examining perceived organizational motives and public responses. Public Relations Review, doi: 10.1016/j.pubrev.2019.101856

Kriz gazete ilanı ile çözülür mü? (2 Ocak 2012). Erişim: 24 Aralık 2020, www.aksam.com.tr

Nike'ı yaktı! Bir anda 3,7 milyar doları silindi. (2018, Eylül). HaberTürk. Erişim: 24 Aralık 2020, https://www.haberturk.com/nike-i-yakti-2130592-ekonomi

Ogisi, A. (11 Ocak 2018). H\&M crisis 2018, "How did they simply let this slip out". Erişim: 24 Aralık 2020, https://www.linkedin.com/pulse/hm-crisis-2018-how-did-simply-let-slip-outaritetsoma-ogisi

Öksüz, B. ve Kölgelier, Y. Ö. (2018). Nutellam olmadan asla: kriz iletişiminde tüketicilerin marka savunuculuğu, 4. EMI Girişimcilik ve Sosyal Bilimler Kongresi'nde sunulan bildiri, 29-30 Kasım 2018, İstanbul, Erişim adresi: http://www.emissc.org.

Öztürk, A. (2010). Marka iletişiminin kriz dönemlerinde işletme performansına etkisi ve hazır giyim işletmeleri üzerine bir araştırma. (Doktora tezi). Selçuk Üniversitesi, Konya

Peltekoğlu, F. B. (2016). Halkla ilişkiler nedir?. İstanbul: Beta kitap.

P\&G iyilikle güçleneceğimiz geleceğe doğru, aynı çatı altında umutla yarına projesini başlatıyor. P\&G. Erişim: 22 Mayıs 2020 , Erişim adresi: https://www.pg.com.tr/blogs/umut2020/

Sezgin, F. (2003). Kriz yönetimi. Kırgızistan Türkiye Manas Üniversitesi Sosyal Bilimler Dergisi, 8(1), 181-195.

Sivil Toplum Kuruluşları Algısı Araştırma Sonuçları. (Temmuz-Ağustos 2018). Brandcore. Erişim adresi: https://docplayer.biz.tr/137614545-Kriz-geliyorum-demiyor-linc-ediyor.html

Schwartz, A. (2016). Crisis communication in an era of hybridization and globalization: Mapping the field of organizational strategic crisis communication and future avenues of research. T. Mercado Saez, M. Chávez ve S. Núñez Hrsg. (ed), içinde Estrategias de comunicación en situaciones de riesgo y crisis / Strategies of risk and crisis communication.

Social media trends, (2019). Hootsuite. Erişim: 20 Aralık 2020, Erişim adresi: 


\section{MEIDIAJ}

www.hootsuite.com

Sosyal linçler, marka krizleri ve itibar araştırma sunumu. (Haziran 2018) Zenna. Erişim adresi: http://www.repman.com.tr

Tekstil devi H\&M'e uluslararası tepkiler bitmiyor. (Şubat 2018). Marketing Türkiye. Erişim: 21 Aralık 2020, https://www.marketingturkiye.com.tr

Tezel, M. (28 Ocak 2020). Berna Laçin'in Elazığ depremi tweetine tepkiler büyüyor!. Sabah Gazetesi. Erişim: 30 Ocak 2020, www.sabah.com.tr

Turkcell'in Ensar Vakfı davasına mahkemeden ret. (2017, Aralık). Sputnik. Erişim: 24 Nisan 2020, https://tr.sputniknews.com/turkiye

Üçhisarlı, C. (8 Ocak 2018). H\&M ırkçılık ile suçlanıyor. Pazarlamasyon. Erişim adresi: https://pazarlamasyon.com

van, Dijk, J. (2018). Ağ toplumu, İstanbul, Kafka Yayınları.

Wheeler, A. (2019). Crisis communication management. Bingley: Emerald Publishing Ltd.

Yenice, A., Pirtini, S. ve Ataman, G. (2018). Sosyal medyada kriz yönetimi ve kurum itibarı ile ilişkisi üzerine bir model uygulaması. Kırklareli Üniversitesi İktisadi ve İdari Bilimler Fakültesi Dergisi, 8, 7(3), 1-20.

Young, C., Simmons, H. ve Stewart, M.C. (2019). Social listening during crisis: a practitioner guide for communication on social media, Proceedings of the International Crisis and Risk Communication Conference, Mart 11-13, Orlando, ABD, doi: 10.30658/icrcc.2019.11 